УДК: 616.83-053.3:616.9-053.1

DOI: 10.24061/2413-4260.VII.2.24.2017.3

\section{I.I.Редько, О.М.Чакмазова, Р.В.Поздняков}

Д3 «Запорізька медична академія післядипломної освіти МОЗ України»

Дитяча лікарня №1

(м. Запоріжжя, Україна)
ОСОБЛИВОСТІ УРАЖЕННЯ ЦЕНТРАЛЬНОЇ НЕРВОВОЇ СИСТЕМИ У НОВОНАРОДЖЕНИХ ПРИ ВНУТРІШНЬОУТРОБНИХ ВІРУСНИХ ІНФЕКЦІЯХ

\title{
Резюме
}

Bступ. Внутрішньоутробні інфекиії з ураженням иентральної нервової системи залишаються актуальною проблемою сучасної перинатології, неонатології та педіатрії і відносяться до групи захворювань, діагностика яких пов'язана з певними труднощами. Кількість збудників внутрішньоутробних інфекиій при анте-, інтра- та перинатальному інфікуванні практично не обмежено. Проте, одне з перших місиь належить збудникам вірусних інфекиій, розповсюдженість яких не уточнена у зв'язку з труднощами діагностики.

Мета дослідження: визначити особливості ураження иентральної нервової системі у новонароджених при внутрішньоутробних інфекиіях на підставі результатів верифікації етіологічних чинників, оиінки факторів ризику перинатального анамнезу та особливостей клінічного перебігу внутрішньоутробних інфекиій.

Матеріали та методи. Проведено клініко-лабораторне обстеження 834 матерів та їх хворих новонароджених з підозрою на внутрішньоутробні інфекиії в перші 3 доби життя. Предметом дослідження стала група з 224 хворих новонароджених з вродженими вірусними інфекиіями. Контрольну групу склали 30 умовно здорових новонароджених. Використовували методи загальноклінічні та спеціального дослідження (люмінісцентна мікроскопія, культуральний метод, полімеразна ланџюгова реакція, серодіагностика). Матеріалом для обстеження у дітей та матерів були кров із пуповинної та периферійної вен, фекалії. Статистична обробка проводилася з обчисленням параметричних та непараметричних критеріїв.

Результати досліджень. Серед загальної кількості обстежених новонароджених з підозрою на вроджену інфекиію, вроджені вірусні інфекиії верифіковані у 224 (31,6\%). Серед них доношених - 132 (58,9\%), недоношених - 92 (41,1\%). Серед 224 дітей верифіковано: у 77 (34,4\%) - мікст-вірусні інфекиії, у 62 (27,7\%) - вірусно-бактеріальні інфекиії, у 53 (23,6 \%) - мікст-вірусно-ТОRCH-інфекиії та моновірусні інфекиії - у 32 (14,3\%). Доведено, щьо всі діти мали різні клінічні варіанти неврологічних порушень. .Найчастішими факторами перинатального ризику є гострі респіраторні інфекиії у вагітних, загроза переривання вагітності, анемії вагітних, дострокове родорозрішення, плачентарна дисфункиія, прееклампсія, асфіксія при народженні. При верифікації етіологічного збудника вірус грипу А визначений у 15,6\%, парагрипу - у 20,5\%, аденовірус - у 40,6\%, РС-вірус - у 27,2 \% та ентеровіруси - у 48,2 \%, иитомегаловірус - у 56,6\%, вірус простого герпесу - у 22,6\%. Доведено, щзо поряд із тяжкими ураженнями иентральної нервової системи у вигляді набряку мозку, внутрішньочерепних крововиливів, менінгоенцефалітів можлива наявність гіпоксично-ішемічних уражень з синдромом пригнічення, гіпертензійно-гідрочефального синдрому або з нечітко вираженою неврологічною симптоматикою при народженні та у перші доби життя у вигляді м'язової дистонії, помірного тремора. Характерними ознаками на нейросонограмі при моновірусних інфекціях були переважно гіпоксично-ішемічні структурні зміни, при мікст-формах вірусних інфекцій переважали ознаки внутрішньошлуночкові крововиливи I або II ступеня, субепендимальні кисти та ознаки вентрикуліту.

Висновки. Висока частота (31,6\%) виділення вірусів у хворих новонароджених з групи ризику по внутрішньоутробній інфекції та їх матерів, особливості клінічного перебігу внутрішньоутробних вірусних інфекцій $з$ ураженням иентральної нервової системи мотивує проведення ранньої клінічної та лабораторної діагностики.

Ключові слова: внутрішньоутробна вірусна інфекиія; ураження иентральної нервової системи; перинатальні фактори ризику; новонароджені; діагностика; особливості клінічного перебігу.

\section{Вступ}

Внутрішньоутробні інфекції (ВУІ) з ураженням центральної нервової системи (ЦНС) у новонароджених (НH) залишаються актуальною проблемою сучасної перинатології, неонатології та педіатрії, так як впливають на показники не тільки малюкової, неонатальної летальності та захворюваності, але й визначають стан інвалідизації у дітей різних вікових груп $[1,2,3,4]$. Частота уражень ЦНС при ВУІ дуже висока. За даними патологоанатомічних досліджень, при морфологічному дослідженні головного мозку у плодів та НН, які померли від різних ВУІ, запальний процес в ньому був виявлений у всіх випадках, у більшості мав місце повільно прогресуючий енцефаліт $[5,6]$. Кількість збудників ВУІ 3 ураженням ЦНС при анте-, інтра- та перинаталь- ному інфікуванні практично не обмежено. Проте, одне 3 перших місць належить збудникам вірусних інфекцій $[7,8,9]$. Серед вірусів перше місце за частотою займають вірус простого герпесу (ВПГ) та цитомегаловірус (ЦМВ), а також ураження викликають респіраторні віруси (грипа, парагрипа, краснухи) та ентеровіруси $[6,10,11,12]$. Ділянки головного мозку, на які діють збудники ВУІ та гіпоксичні стани, часто співпадають, що утруднює їх диференціацію. Ступінь ураження ЦНС при ВУІ залежить від виду збудника, локалізації процесу та характеру захворювання.

Незважаючи на значні успіхи, досягнуті за останні десятиріччя у боротьбі 3 інфекційними захворюваннями, ВУІ з ураженням ЦНС представляють серйозну соціальну проблему, розпо- 
всюдженість яких до кінця не уточнена 3 причини відсутності та складності діагностики

Мета - визначити особливості ураження центральної нервової системі у новонароджених при внутрішньоутробних інфекціях на підставі результатів верифікації етіологічних чинників, оцінки факторів ризику перинатального анамнезу та особливостей клінічного перебігу внутрішньоутробних інфекцій.

\section{Матеріали та методи}

Проведено клініко-лабораторне обстеження 834 матерів та їх хворих новонароджених 3 підозрою на ВУІ в перші 3 доби життя. Предметом поглибленого дослідження стала група 3224 хворих НН 3 вродженими вірусними інфекціями (BBI).

Використовували методи загальноклінічні та спеціального дослідження. Етіологічна верифікація ВУІ проводилась в перші 3 доби життя при надходженні дитини у неонатологічне відділення пологових будинків або у відділення реанімації, та у їх матерів після пологів.

Специфічна діагностика ентеровірусної інфекції проводилася за допомогою культурального методу 3 використанням курячих ембріонів (HEL) та модифікованої реакції зв'язування комплементу (м-РЗК) із застосуванням полі- та моновалентних ентеровірусних діагностичних сироваток на імуноферментному аналізаторі. Матеріалом для обстеження у дітей та матерів були кров із пуповинної та периферійної вен, фекалії. Специфічну діагностику інфекцій групи TORCH проводили методом імуноферментного аналізу та полімеразної ланцюгової реакції. Матеріалом для обстеження у дітей були кров, сеча, слина та ліквор, у матерів - кров. Специфічна діагностика вроджених грипу, парагрипу, аденовірусної (АД) та респіраторно-синцитіальної (РС) інфекцій проводилася за допомогою методів прямої імунофлюоресценції, імунохроматографічного аналізу, серодіагностики (парні сироватки в реакції пасивної гемаглютинації) та на підставі результатів гістологічного та цитологічного дослідження послідів. Матеріалом для обстеження у дітей та матерів були змиви та зіскоби 3 носоглотки, кров із пуповинної та периферійної вен.

Бактеріологічне обстеження НН та їх матерів проведено дворазово при надходженні дитини до відділення реанімації або до неонатального відділення пологового будинку та в динаміці перебування в стаціонарі. Матеріалом для бактеріологічного дослідження у дітей були фекалії, змиви 3 носоглотки, гній, кров, ліквор, у матерів - змиви 3 носоглотки, виділення 3 піхви.

Статистична обробка отриманих результатів проводилася 3 обчисленням параметричних та непараметричних критеріїв.

\section{Результати дослідження та їх обговорення}

Серед загальної кількості обстежених НН з підозрою на ВУІ, ВВІ верифіковано у 224 (31,6\%). Серед них доношених - 132 (58,9\%), недоношених - 92 (41,1\%). Серед 224 дітей верифіковано: у $77(34,4 \%)$ - мікст-вірусні інфекції, у $62(27,7 \%)$ - вірусно-бактеріальні інфекції, у 53 (23,6\%) - мікствірусно-TORCH-інфекції та моновірусні інфекції - у 32 (14,3%). При верифікації етіологічного збудника вірус грипу А визначений у $15,6 \%$, парагрипу - у $20,5 \%$, аденовірус - у $40,6 \%$, РС-вірус - у $27,2 \%$ та ентеровіруси - у 48,2\%, цитомегаловірус - у 56,6\%, вірус простого герпесу - у 22,6\%.

На підставі м-РЗК вперше визначена роль різ- них серологічних типів ентеровірусів в структурі BBI у НН з ураженням ЦНС, серед яких переважали серотипи ентеро 68-71 - у 67 (62,0\%), ЕСНО - у 32 $(29,6 \%)$ та Коксакі В - у 15 (13,9\%). Сполучення двох серотипів ентеровірусів спостерігали у 12 $(11,1 \%)$ дітей та їх матерів.

Найчастішими факторами перинатального ризику розвитку вроджених вірусних інфекцій у новонароджених є наявність гострих респіраторних вірусних інфекцій (ГРВІ) у вагітних $(45,5 \%)$, загроза переривання вагітності $(43,7 \%)$, дострокові пологи $(41,1 \%)$, анемія $(25,0 \%)$, плацентарна дисфункція $(23,2$ \%), прееклампсія $(17,4 \%)$, асфіксія при народженні (40,6 \%).

Серед ускладнень вагітності переважали ГРВІ, які вагітні жінки частіше переносили у III триместрі вагітності $(\mathrm{p}<0,05)$. При цьому обтяжений перебіг вагітності та пологів відмічався не тільки у вагітних 3 маніфестними формами гострої респіраторної інфекції, але і з інапарантними формами. Несприятливим фактором для плоду також була наявність у більшості жінок загострень хронічних генітальних та екстрагенітальних інфекцій під час даної вагітності, лікування яких або не проводилося, або проводилося без ефективної санації, про що може свідчити високий відсоток недоношених НН у групах із мікствірусними та вірусно-бактеріальними інфекціями.

Вивчено особливості уражень ЦНС при ВВI у НН. При моновірусних інфекціях доношених було 93,7\%, недоношених - 6,3\% (з гестаційним віком 35-36 тижнів). Ураження ЦНС у недоношених характеризувалося синдромом пригнічення та за етіологічним фактором верифіковано РС-вірус та вірус парагрипа, на НСГ ВШК І ступеня (субепендимальні кисти (СЕК) бокових шлуночків). Ураження ЦНС у доношених характеризувалося синдромами підвищеної нервово-рефлекторної збудливості та вегето-вісцеральних порушень. Серед етіологічних факторів верифіковано ентеровіруси (серотипи Е-68, 69, ЕСНО, Коксакі В), аденовірус, РС-вірус, на НСГ - гіпоксично-ішемічні зміни, СЕК в бокових шлуночках. В даній групі летальності не зареєстровано.

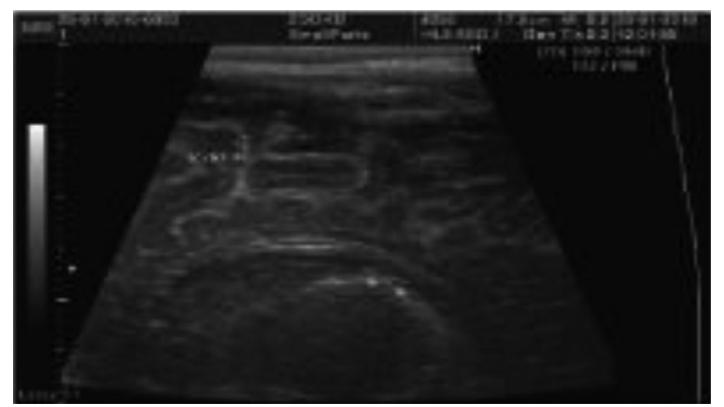

Рис 1. Дитина 7 днів НСГ: СЕК в області лівого бокового шлуночку. Діагноз: внутрішньоутробна парагрипозна інфекція

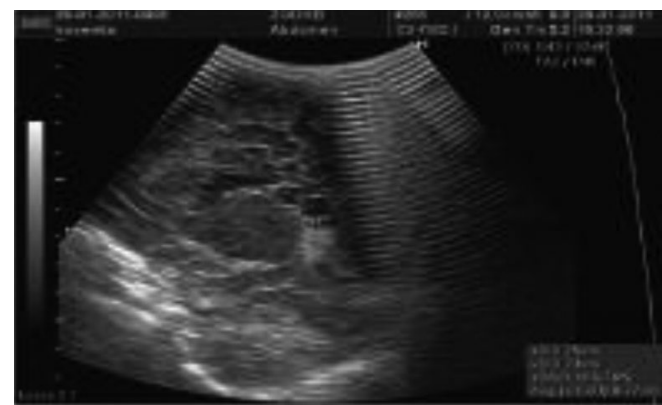

Рис 2. Дитина 10 днів. НСГ: СЕК в області каудодапамичної бороди. Діагноз: внутрішньоутробна вірусна РС-інфекція 


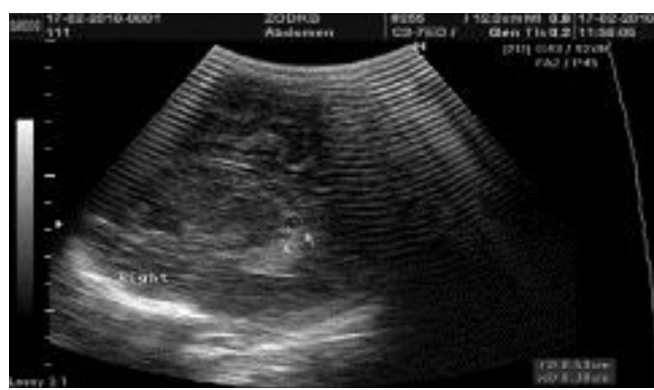

Рис 3. Дитина 10 днів НСГ: киста судинного сплетіння правого бокового шлуночку в середній третині. Діагноз: внутрішньоутроюбна мікст-вірусна інфекція (коксаки-В6+парагрип)

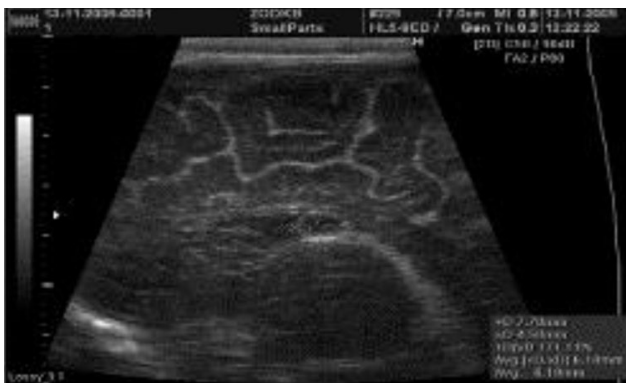

Рис 4. Дитина 8 днів НСГ: СЕК в області каудотапамичної бороди. Діагноз: внутрішньоутробна мікст-вірусна інфекція (грип А+АД-інфекція)

При мікст-вірусно-вірусних інфекціях доношених було $54,5 \%$, недоношених $-45,5 \%$ (з гестаційним віком 25-36 тижнів). Ураження ЦНС у недоношених характеризувалося синдромом пригнічення. Серед етіологічних факторів переважали асоціації віруса грипа 3 парагрипом, з РС-вірусом, 3 аденовірусом, найбільш важке ураження при асоціації ентеровіруса Коксакі В6 та парагрипа. На НСГ спостерігались ознаки незрілості мозкової тканини сполуці 3 гіпоксично-ішемічними змінами: перивентрикулярний венозний ішемічний набряк, ВШК I-II ступеня, кисти судинних сплетінь бокових шлуночків. Ураження ЦНС у доношених характеризувалося синдромом підвищеної нервово-рефлекторної збудливості при верифікації РC-віруса в асоціації 3 аденовірусом та вірусом парагрипа, асоціація аденовіруса 3 ентеровірусом (E-68, 69). На НСГ: ВШК I-II ступеня в сполуці 3 вентрикулітом, субепендимальні кисти. В даній групі летальність склала 3,9\% серед недоношених при верифікації РС-віруса в асоціації 3 вірусом грипа А та аденовірусом.

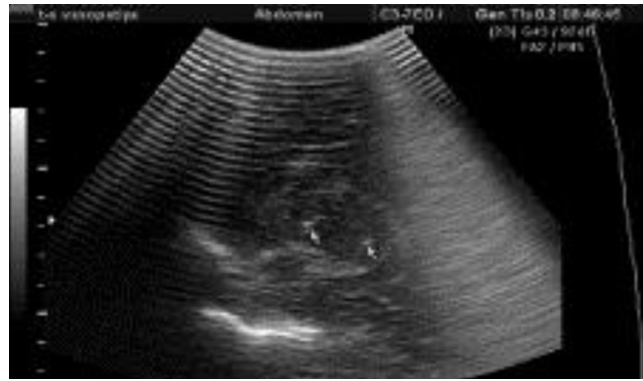

Рис 5. Дитина 10 днів НСг: таламостріальна вазопатія, двохсторонні кисти судинних сплетінь бокових шлуночків. Діагноз: внутрішньоутробна мікст-вірусна інфекція (Коксаки-В6+парагрип)

При мікст-вірусно-бактеріальних інфекціях недоношених було 51,6\% (з гестаційним віком 25 -
36 тижнів), доношених - 48,4\%. Ураження ЦНС у недоношених характеризувалося синдромом пригнічення, на НСГ - ВШК II ступеня. Ураження ЦНС у доношених характеризувалося синдромом підвищеної нервово-рефлекторної збудливості, на НСГ - гіпоксично-ішемічні зміни, ВШК І ступеня. При верифікації етіологічного чинника як у доношених, так і недоношених НН переважали віруси грипа А, вірус парагрипа, Коксакі В6, РСвірус. Летальність в даній групі - 11,3\% (переважала РС-інфекція).

При мікст-вірусно-TORCH інфекціях доношених було 56,6\%, недоношених 43,4\% (з ГВ 29-36 тиж.). Ураження ЦНС у недоношених характеризувалося ізольованою церебральною формою (підгострий енцефаліт), у доношених - синдром пригнічення або гіпертензійно-гідроцефальний синдром. При верифікації етіологічного чинника виділено віруси парагрипа РС-вірус, АД-вірус, ентеровіруси (Коксакі В-6, ЕСНО) в асоціації 3 ЦМВ, ВПГ, токсоплазмозом. На НСГ: ВШК II-III ст.; підвищена ехогенність білої речовини головного мозку, септальні перегородки в області бокових шлуночків, кисти судинних сплетінь бокових шлуночків, гиперехогенні включення в таламусах (кальцинати). Летальність в даній групі - 3,7\% cеред недоношених.

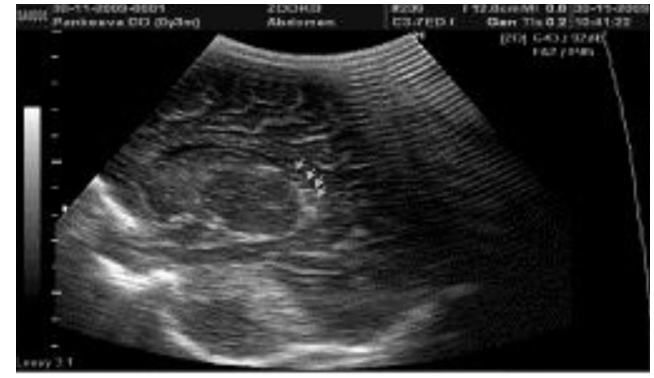

Рис 6. Дитина 9 днів НСГ: дрібні кисти судинного сплетіння правового бокового шлуночку в середній третині. Діагноз: внутрішньоутробна мікст-вірусна TORCH-інфекція (ЦМБ+коксаки-B6)

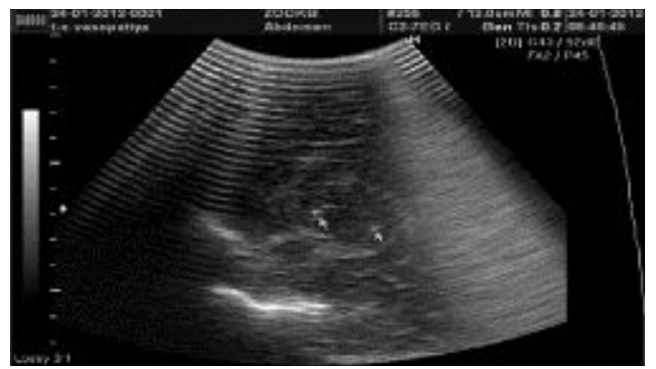

Рис 7. Дитина 10 днів НСГ: гіперохогенні

включення в тапамісах (кальцинати). Діагноз: внутрішньоутробна мікст-вірусна TORH-інфекція (ЦМБ+коксаки-В6)

\section{Висновки}

1. При внутрішньоутробних вірусних інфекціях мають місце різні клінічні варіанти неврологічних порушень як у доношених, так і у недоношених новонароджених.

2. Висока частота $(31,6 \%)$ виділення вірусів у хворих новонароджених 3 групи ризику по внутрішньоутробній інфекції та їх матерів, особливості клінічного перебігу внутрішньоутробних вірусних інфекцій мотивує проведення ранньої клінічної та лабораторної діагностики

3. Найчастішими факторами перинатального ризику розвитку ВBI у новонароджених $\epsilon$ наявність ГРВІ у вагітних, загроза переривання ва- 
гітності, дострокові пологи, анемія, плацентарна дисфункція, прееклампсія.

4. Встановлено, що найбільш тяжке ураження ЦНС з високим ризиком летальності спостерігається при мікст-вірусно-бактеріальних та мікствірусно-TORCH інфекціях у недоношених новонароджених.

5. Характерними ознаками на НСГ при мікст- формах вроджених вірусних інфекцій є ВШК I-III ступеня, субепендимальні кисти, кисти судинних сплетінь бокових шлуночків мозку, ознаки вентрикуліту.

6. На підставі застосування експрес-методу діагностики (м-РЗК) визначена роль ентеровірусів серотипів 68-71 та різних серотипів ЕСНО в ураженні ЦНС у новонароджених при вроджених вірусних інфекціях.

\section{Література}

1. Айкарди Ж, редактор. Заболевания нервной системы у детей. В 2-х т. Москва: Издательство Панфилова; 2013. Т. 1. 568 с.

2. Всемирный доклад об инвалидности [Интернет]. Женева: Всемирная организация здравоохранения; 2011. [процитировано 2017 Май 19]; 28 с. Доступно: http://www.who.int/disabilities/world report/2011/ summary_ru.pdf?ua=1

3. Евтушенко СК, редактор. Неврология раннего детского возраста. Киев: Заславский АЮ; 2016.288 с.

4. Мартинюк ВЮ, редактор. Основи соціальної педіатрії: навч.-метод. посіб. У 2-х т. Київ: ФОП Верес OI; 2016. T. 2. 480 c.

5. Знаменська ТК, редактор. Неонатологія: навч. посіб. Київ: Асоціація неонатологів України; 2012. с. $576-643$.

6. Знаменська TК, редактор. TORCH-инфекции в акушерстве и неонатологии. Киев: Standart Digital Print; 2008. 200 c.

7. Долгушина НМ, Макацария АД. Вирусные инфекции у беременных: руководство для врачей. Москва: Триада-Х; 2009. 144 с.

8. Макаров ОВ, редактор. Инфекции в акушерстве и гинекологии. 2-е изд. [Интернет]. Москва: МЕДпресс-информ; 2009 [процитировано 2017 Май 19]; 464 с. Доступно: http://www.med-press.ru/upload/ iblock/ fad/226_Infekcija_akusherstve_ginekologiicMakarovr.pdf

9. Marino T, Viral Infections and Pregnancy. Medscape [Internet]. 2011 [cited 2017 May 19]. Available from: http://emedicine.medscape.com/article/235213-overview

10. Шунько СЄ, редактор. Неонатологія: національний підручник. В 2-х т. Київ; 2014. Т. 1. с. 80-102.

11. Boyer SG, Boyer KM. Update on TORCH Infections in the Newborn Infant. Medscape [Internet]. 2011 [cited 2017 May 19]. Available from: http://www.medscape.com/viewarticle/472409

12. Tregoning JS, Schwarze J. Respiratory Viral Infections in Infants: Causes, Clinical Symptoms, Virology, and Immunology. Clin Microbiol Rev. 2010 Jan; 23(1):74-98. doi: 10.1128/CMR.00032-09

\section{ОСОБЕННОСТИ ПОРАЖЕНИЯ ЦЕНТРАЛЬНОЙ НЕРВНОЙ СИСТЕМЫ У НОВОРОЖДЕННЫХ ПРИ ВНУТРИУТРОБНЫХ ВИРУСНЫХ ИНФЕКЦИЯХ}

\section{И.И.Редько, О.М.Чакмазова, Р.В.Поздняков}

ГУ «Запорожская медицинская академия последипломного образования МЗ Украины»

Детская больница №1

(г. Запорожье, Украина)

\section{Резюме}

Введение. Внутриутробные инфекции с поражением центральной нервной системы остаются актуальной проблемой современной перинатологии, неонатологии и педиатрии и относятся к группе заболеваний, диагностика которых связана с определенными трудностями. Количество возбудителей внутриутробных инфекций при анте, интра- и перинатальном инфицировании практически не ограничено. Однако, одно из первых мест принадлежит возбудителям вирусных инфекций, распространенность которых не уточнена в связи с трудностями диагностики.

Цель исследования: определить особенности поражения центральной нервной системы у новорожденных при внутриутробных инфекциях на основании результатов верификации этиологических возбудителей, оценки факторов риска перинатального анамнеза и особенностей клинического течения внутриутробных инфекций.

Материалы и методы. Проведено клинико-лабораторное обследование 834 матерей и их больных новорожденных с подозрением на внутриутробные инфекции в первые 3 суток жизни. Предметом исследования стала группа из 224 больных новорожденных

\section{FEATURES OF CENTRAL NERVOUS SYSTEM DEFEAT \\ IN NEWBORNS WITH INTRAUTERINE VIRAL INFECTIONS}

\section{I.I. Redko, O.M. Chakmazova, R.V. Pozdnyakov}

State Institution "Zaporozhzhye Medical Academy of Postgraduate Education

of the Ministry of Health of Ukraine", Children's Hospital №1

(Zaporozhzhye, Ukraine)

\section{Summary.}

Introduction. Intrauterine infections with central nervous system lesions remain an urgent problem of modern perinatology, neonatology and pediatrics and belong to a group of diseases whose diagnosis is associated with certain difficulties. The number of pathogens of intrauterine infections with an ante, intra- and perinatal infection is practically unlimited. However, one of the first places belongs to the causative agents of viral infections, the prevalence of which not specified in connection with the difficulties of diagnosis.

The purpose of the study was to determine the features of central nervous system damage in newborns with intrauterine infections based on the results of the verification of etiologic pathogens, the evaluation of risk factors for perinatal history and the specific features of the clinical course of intrauterine infections.

Materials and methods. Clinical laboratory examination of 834 mothers and their sick newborns with suspicion of intrauterine infections in the first 3 days of life was performed. The subject of the study was a group of 224 patients with newborns with congenital viral infections. The control group consisted of 30 conditionally 
с врожденными вирусными инфекциями. Контрольную группу составили 30 условно здоровых новорожденных. Использовали методы общеклинические и специального исследования (люминесцентная микроскопия, культуральный метод, полимеразная цепная реакция, серодиагностика). Материалом для обследования у детей и матерей были кровь из пуповинной и периферической вен, фекалии. Статистическая обработка проводилась с вычислением параметрических и непараметрических критериев.

Результаты исследований. Среди общего количества обследованных новорожденных с подозрением на врожденную инфекцию, врожденные вирусные инфекции верифицированы у 224 (31,6\%). Среди них доношенных - 132 (58,9\%), недоношенных - 92 (41,1\%). Среди 224 детей верифицированы: в 77 (34,4\%) - микст-вирусные инфекции, в $62(27,7 \%)$ - вирусно-бактериальные инфекции, в $53(23,6 \%)$ - микст-вирусно-ТORCH-инфекции и моновирусные инфекции - у 32 (14,3\%). Доказано, что все дети имели различные клинические варианты неврологических нарушений. Среди факторов перинатального риска преобладают острые респираторно-вирусные инфекции у беременных, угроза прерывания беременности, анемии беременных, досрочное родоразрешение, плацентарная дисфункция, преэклампсия, асфиксия при рождении. При верификации этиологического возбудителя вирус гриппа А определен в $15,6 \%$, парагриппа в $20,5 \%$, аденовирус - в $40,6 \%$, РС-вирус - в $27,2 \%$ и энтеровирусы - в $48,2 \%$, цитомегаловирус - в $56,6 \%$, вирус простого герпеса - в 22,6\%. Доказано, что наряду с тяжелыми поражениями центральной нервной системы в виде отека мозга, внутричерепных кровоизлияний, менингоэнцефалитов возможно наличие гипоксически-ишемических поражений с синдромом угнетения, гипертензионно-гидроцефальным синдромом или нечетко выраженной неврологической симптоматикой при рождении и в первые сутки жизни в виде умеренной мышечной дистонии и тремора. Характерными признаками на нейросонограмме при моновирусних инфекциях были преимущественно гипоксически-ишемические структурные изменения, при микст-формах вирусных инфекций преобладали признаки внутрижелудочковых кровоизлияний I или II степени, субэпендимальные кисты и признаки вентрикулита.

Выводы. Высокая частота $(31,6 \%)$ выделения вирусов у больных новорожденных из группы риска по внутриутробной инфекции и их матерей, особенности клинического течения внутриутробных вирусных инфекций с поражением центральной нервной системы мотивирует проведение ранней клинической и лабораторной диагностики.

Ключевые слова: внутриутробная инфекция; поражение центральной нервной системы; перинатальные факторы риска; новорожденные; диагностика; особенности клинического течения.

Контактна інформація:

Редько Ірина Іванівна - д.мед.н., професор кафедри педіатрії та неонатології з курсом амбулаторної педіатрії ДЗ «Запорізька медична академія післядипломної освіти МОЗ України» (м.Запоріжжя, Україна)

Контактна адреса: вул. Героїв Сталінграда, 25/379, м.Запоріжжя, 69002, Україна.

Контактний телефон:

$+38(050) 5614125$

E-mail: redkoirina61@gmail.com healthy newborns. The methods were general clinical and special studies (luminescence microscopy, culture method, polymerase chain reaction, sero diagnostics). Materials for examination in children and mothers were blood from the umbilical and peripheral veins, feces. Statistical processing was carried out with the calculation of parametric and nonparametric criteria.

Results of the research. Among the total number of examined newborns with suspected congenital infection, congenital viral infections were verified in 224 (31.6\%). Among them, term infants - $132(58.9 \%)$, premature babies 92 (41.1\%). Among 224 children, 77 (34.4\%) mixed virus infections, $62(27.7 \%)$ viral and bacterial infections, 53 $(23.6 \%)$ mixed-virus-TORCH infections and mono viral infections - in $32(14.3 \%)$. It proved that all children had different clinical variants of neurological disorders. Among the factors of perinatal risk are acute respiratory infections in pregnant women, the threat of abortion, anemia of pregnant women, early delivery, placental dysfunction, preeclampsia, birth asphyxia. When the etiologic pathogen was verified, the influenza A virus was defined in $15.6 \%$, parainfluenza in $20.5 \%$, adenovirus in $40.6 \%$, the PC virus in $27.2 \%$ and enterovirus in $48.2 \%$, cytomegalovirus - in $56.6 \%$, the herpes simplex virus - in $22.6 \%$. It is proved that along with severe lesions of the central nervous system in the form of cerebral edema, intracranial hemorrhages, meningoencephalitis, hypoxicischemic lesions with oppression syndrome, hypertensive hydrocephalic syndrome or indistinct neurologic symptoms at birth and in the first day of life in the form of moderate muscular dystonia and tremors. Characteristic signs on the neurosonogram in monovirus infections were predominantly hypoxic-ischemic structural changes, with mixed forms of viral infections, signs of intraventricular hemorrhages of I or II degree, subependimal cysts and signs of ventriculitis predominated.

Conclusions. High frequency (31.6\%) of virus isolation in patients with newborns at risk for intrauterine infection and their mothers, features of the clinical course of intrauterine viral infections with central nervous system damage motivate early clinical and laboratory diagnosis.

Key words: intrauterine infection; central nervous system damage; perinatal risk factors; newborns; diagnostics; clinical course features.
Контактная информация:

Редько Ирина Ивановна, д-р мед. наук, профессор кафедры педиатрии и неонатологии с курсом амбулаторной педиатрии ГЗ «Запорожская медицинская академия последипломного образования МЗ Украины» (г.Запорожье, Украина)

Контактный адрес: ул. Героев Сталинграда, 25/379, Запорожье, 69002 Украина.

Контактный телефон:

+38 (050) 5614125

E-mail: redkoirina61@gmail.com

\section{Contact Information:}

Redko I.I. - MD, PhD, Dsci, Professor of the Depatment of Pediatrics and Neonatology with the course of outpatient pediatrics State Institute "Zaporizhzhia Medical Academy of Postgraduate Education of Ministry of Health of Ukraine" (Zaporozhzhye, Ukraine)

Contact address: Heroes of Stalingrad str., 25/379, Zaporozhye 69002, Ukraine.

Telephone: +38 (050) 5614125

E-mail: redkoirina61@gmail.com 